\title{
Late Quaternary paleoenvironment of the Ross Sea continental shelf, Antarctica
}

\author{
Akira Nishimura, ${ }^{1}$ Toru Nakasone, ${ }^{2}$ Chikara Hiramatsu, ${ }^{3}$ Manabu Tanahashi ${ }^{4}$ \\ ${ }^{1}$ Marine Geology Department, Geological Survey of Japan, 1-3, Higashi 1-chome, Tsukuba, Ibaraki 305, Japan \\ ${ }^{2}$ Kawasaki Chishitsu Co. Ltd., 23-17, Omori-minami 3-chome, Ota-ku, Tokyo 143, Japan \\ ${ }^{3}$ JAPEX Research Center, Japan Petroleum Exploration Co. Ltd., 2-1, Hamada 1-chome, Mihama-ku, Chiba 261, Japan \\ ${ }^{4}$ Technology Research Center, Japan National Oil Corporation, 2-2, Uchisaiwai-cho 2-chome, Chiyoda-ku, Tokyo 100, Japan
}

\begin{abstract}
Based on sedimentological and micropaleontological work on three sediment cores collected at about $167^{\circ} \mathrm{E}$ in the western Ross Sea, Antarctica, and accelerator mass spectrometer ${ }^{14} \mathrm{C}$ ages of organic carbon, we have reconstructed environmental changes in the area during the late Quaternary. Since $38 \mathrm{ka} \mathrm{BP}$ at latest, this area was a marine environment with low productivity. A grounded ice sheet advanced and loaded the sediments before about $30-25 \mathrm{ka} \mathrm{BP}$. After $25 \mathrm{ka} \mathrm{BP}$, the southernmost site $\left(76^{\circ} 46^{\prime} \mathrm{S}\right)$ was covered by floating ice (shelf ice), preventing deposition of coarse terrigenous materials and maintaining a supply of diatom tests and organic carbon until $20 \mathrm{ka}$ BP. The northernmost site $\left(74^{\circ} 33^{\prime} \mathrm{S}\right)$ was in a marine environment with a moderate productivity influenced by shelf ice/ice sheet after about $20 \mathrm{ka}$ BP. Since about $10 \mathrm{ka}$ BP, a sedimentary environment similar to the present-day one has prevailed over this area.
\end{abstract}

\section{INTRODUCTION}

Marine sediments from the seas around Antarctica are important sources of information on Antarctic environmental changes. The sediments of the Ross Sea, one of the large inlets of Antarctica, have been researched in a number of sedimentological, oceanographic and micropaleontological studies (e.g. Kellogg and others, 1979; Anderson and others, 1984; Edwards and others, 1987; DeMaster and others, 1992), and the recent history of the Antarctic ice sheet has been reconstructed in several studies of this region (e.g. Denton and others, 1989; Anderson and others, 1991). Our previous research has distinguished two types of sediment sequences on the Ross Sea continental shelf: continental-shelf break and continental-shelf facies (Nishimura and others, 1996). The continental-shelf sequence consists of two distinct lithologies: upper diatomaceous mud formed under modern conditions and lower consolidated sandy silt probably of glacial origin. The heavy mineral distribution in the surface sediments suggests that icebergs transported sand grains to the area, controlled by surface currents in the Ross Sea (Tokuhashi and others, 1996). In 1995 we obtained three new cores from the western margin of the Ross Sea continental shelf during a Japan National Oil Corporation (JNOG) research cruise.

In this paper, we describe these cores and infer paleoenvironmental conditions in the western Ross Sea based on sedimentological and micropaleontological data, and accelerator mass spectrometer (AMS) ${ }^{14} \mathrm{C}$ dating of the cores.

\section{GEOLOGIC SETTING}

The continental shelf of the Ross Sea is up to $600 \mathrm{~m}$ deep, with several north-northeast-south-southwest trending banks and troughs. These topographic features result from the structures of sedimentary basins and glacial erosion in the Quaternary (Davey, 1987). The shelf break of the Ross Sea is relatively deep $(\approx 800 \mathrm{~m})$, and the greatest depths on the shelf occur landward near the ice shelf (Chriss and Frakes, 1972). The western margin of the Ross Sea continental shelf is bounded by the Transantarctic Mountains and a deep trough, the Drygalski Basin, present along the coast with a northeast-southwest to north-northeast-southsouthwest trend. To the east of the troughs, there are shallower banks and islands, such as Crary Bank, Franklin Island and Beaufort Island, from north to south. The present ice shelf is south of $77.5^{\circ} \mathrm{S}$ in the western Ross Sea. Drygalski Ice Tongue extends eastward to $165^{\circ} \mathrm{E}$ along $75.5^{\circ} \mathrm{S}$.

The deeper $(>300 \mathrm{~m}$ ) basins of the Ross Sea continental shelf are covered by muddy sediments, whereas shallower areas are covered by coarser (sand and gravel) deposits, reflecting sediment sorting by bottom currents (Anderson and others, 1984; McCoy, 1991). The muddy sediments in the deeper portions consist of terrigenous fine silt and clay, and siliceous biogenic material containing poorly sorted ice-rafted debris (Nishimura and others, 1996).

\section{MATERIALS AND METHODS}

The sediment core samples used in this study were collected from the western margin of the Ross Sea (Fig. 1; Table 1) during the TH95 Antarctic Cruise in 1996 conducted by the Technology Research Center, JNOC, using R/V HakureiMaru. A gravity corer with an $11 \mathrm{~cm}$ diameter and $5.4 \mathrm{~m}$ long was used, but the recovered core lengths were shorter because of the presence of hard substrata in the shallower 


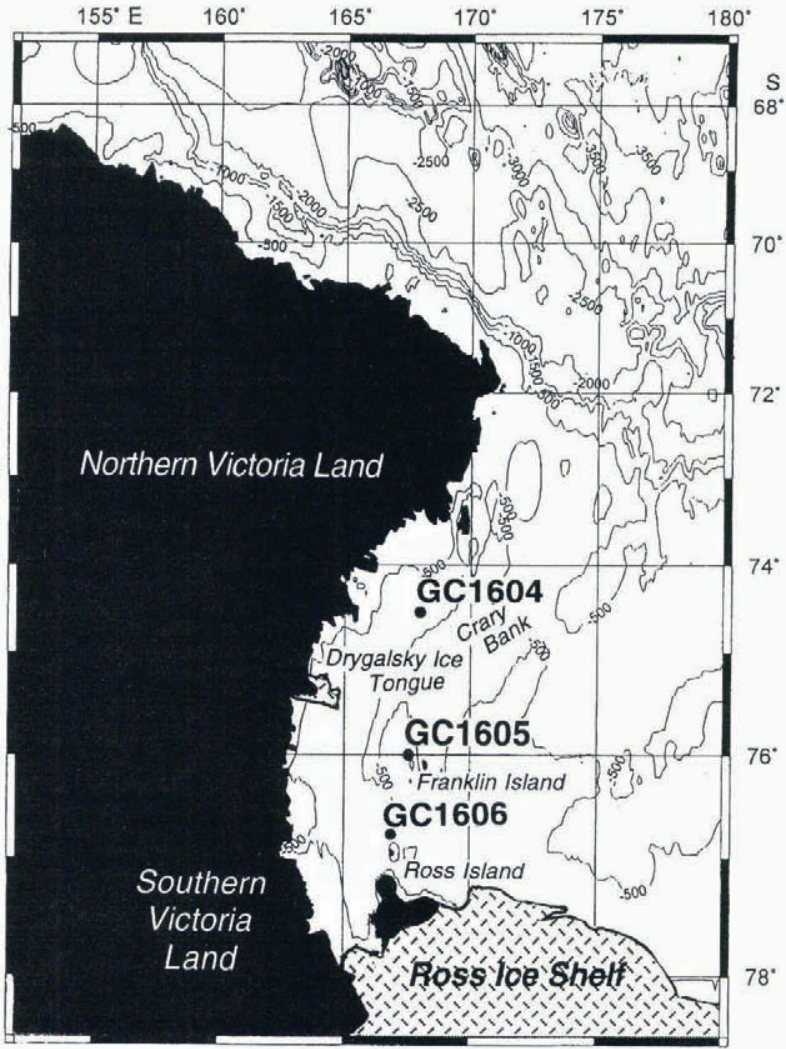

Fig. 1. Map of the western Ross Sea continental shelf, Antarctica, showing the sampling locations.

Table 1. Location data for core samples in the western Ross Sea

\begin{tabular}{lccc}
\hline Sample No. & \multicolumn{2}{c}{ Location } & Water depth \\
& Latitude & Longitude & $\mathrm{m}$ \\
\hline GC1604 & $74^{\circ} 32^{\prime} 55^{\prime \prime} \mathrm{S}$ & $168^{\circ} 00^{\prime} 06^{\prime \prime} \mathrm{E}$ & 922 \\
GC1605 & $76^{\circ} 00^{\prime} 03^{\prime \prime} \mathrm{S}$ & $167^{\circ} 34^{\prime} 30^{\prime \prime} \mathrm{E}$ & 595 \\
GCi606 & $76^{\circ} 46^{\prime} 14^{\prime \prime} \mathrm{S}$ & $166^{\circ} 52^{\prime} 36^{\prime \prime} \mathrm{E}$ & 751 \\
& & & \\
\hline
\end{tabular}

subsea floor. Site GC1604 is situated on the northwestern slope of Crary Bank, east of Mount Melbourne; site GC1605 is situated near Franklin Island; and site GCl606 is located north of Ross Island.

Our shipboard and shore-based studies consisted of seven components:

(1) Descriptions of sediment lithologies based on visual observation, soft X-ray photos and smear slide observations.

(2) Water content (weight percentage water) and dry bulk density were measured for syringe samples of $4-5 \mathrm{~cm}^{3}$ at $10 \mathrm{~cm}$ intervals.

(3) Sand contents (weight percentage of grains larger than $63 \mu \mathrm{m}$ ) were measured for the syringe samples.

(4) Magnetic susceptibilities were measured for $\operatorname{lin}^{3}\left(16 \mathrm{~cm}^{3}\right)$ samples at every inch $(2.54 \mathrm{~cm})$ using a Martison Type-2 apparatus in 0.47 and $4.7 \mathrm{kHz}$ frequency modes. Magnetic susceptibility profiles may be used to infer content of terrigenous materials in the sediments. The frequency dependencies were calculated from the differences of measured susceptibility values between the two modes, and those values suggest the grain-sizes of magnetic minerals (Yamazaki and Katsura, 1990):

$$
X_{\mathrm{FD}}=\left(X_{\mathrm{L}}-X_{\mathrm{H}}\right) / X_{\mathrm{L}} \times 100(\%)
$$

$X_{\mathrm{FD}}$ is the frequency dependence, $X_{\mathrm{L}}$ is the magnetic susceptibility of $0.47 \mathrm{kHz}$ frequency and $X_{\mathrm{H}}$ is the magnetic susceptibility of $4.7 \mathrm{kHz}$ frequency

(5) Organic carbon contents were measured at 10-20 cm intervals. Samples were stored frozen before drying at $50^{\circ} \mathrm{C}$. Bulk carbon contents were measured using a Yanako CHN analyzer; the bulk carbon contents are assumed equal to organic carbon contents, because the inorganic carbon contents of several survey samples are less than $0.04 \%$.

(6) Diatoms were analyzed at $20 \mathrm{~cm}$ intervals using unprocessed strewn slides (Akiba, 1982). One hundred diatom specimens were identified along with resting spores.

(7) Acid-insoluble organic carbon was used for AMS ${ }^{14} \mathrm{C}$ dating. ${ }^{14} \mathrm{C}$ ages (Table 2) are corrected for isotopic fractionation based on ${ }^{13} \mathrm{C} /{ }^{12} \mathrm{C}$ ratios, using a half-life of 5568 years. The AMS measurements were performed at Groningen University, The Netherlands, after preparation at Beta Analytic Inc., U.S.A. Fifteen dates are available for these three cores (Table 2; Fig. 2). We have not made corrections for ${ }^{14} \mathrm{C}$ reservoir effect. We suggest deducting at least $2 \mathrm{ka}$ from our ${ }^{14} \mathrm{C}$ ages, because of core-top ages of about 2 and $3 \mathrm{ka} \mathrm{BP}$.

Table 2. AMS age data of the organic carbon in cores GC1604, GC1605 and GC1606 from the western Ross Sea

\begin{tabular}{|c|c|c|c|c|}
\hline Core No. & $\begin{array}{l}\text { Depth } \\
\mathrm{cm}\end{array}$ & $\begin{array}{l}{ }^{14} \mathrm{CAge} \\
\text { years BP }\end{array}$ & $\begin{array}{c}\delta^{13} C \\
\% 0\end{array}$ & $\begin{array}{c}\text { Corrected }{ }^{14} \text { C Age } \\
\text { years BP }\end{array}$ \\
\hline \multirow[t]{6}{*}{ GC1604 } & $0-5$ & $3450 \pm 60$ & -35.6 & $3280 \pm 60$ \\
\hline & $109-114$ & $9220 \pm 70$ & -31.5 & $9120 \pm 70$ \\
\hline & $133-138$ & $14440 \pm 70$ & -27.7 & $14400 \pm 70$ \\
\hline & $172-175$ & $21200 \pm 170$ & -28.6 & $21140 \pm 170$ \\
\hline & $187-192$ & $36320 \pm 980$ & -27.7 & $36280 \pm 980$ \\
\hline & $244-249$ & $37640 \pm 1130$ & -36.4 & $37460 \pm 1130$ \\
\hline \multirow[t]{2}{*}{ GC1605 } & $24-29$ & $23650 \pm 260$ & -32.9 & $23530 \pm 260$ \\
\hline & $48-53$ & $31540 \pm 570$ & -30.2 & $31460 \pm 570$ \\
\hline \multirow[t]{7}{*}{ GCl606 } & $0-5$ & $2440 \pm 50$ & -31.2 & $2340 \pm 50$ \\
\hline & $40-44$ & $8120 \pm 40$ & -29.7 & $8040 \pm 40$ \\
\hline & $75-80$ & $20540 \pm 180$ & -31.2 & $20440 \pm 180$ \\
\hline & $139-144$ & $24040 \pm 260$ & -32.8 & $23920 \pm 260$ \\
\hline & $178-182$ & $29660 \pm 190$ & -27.8 & $29620 \pm 190$ \\
\hline & $198-204$ & $33430 \pm 690$ & -28.3 & $33380 \pm 690$ \\
\hline & $239-243$ & $32560 \pm 270$ & -27.8 & $32520 \pm 270$ \\
\hline
\end{tabular}

\section{CORE LITHOLOGIES}

In the core sequences, we distinguished three lithologic units, I, II and III in descending order. Unit II is subdivided into unit IIA and IIB. The simplified lithologies and characteristics of the sediments are shown in Figure 2. The results of diatom analysis are shown in Figure 3.

\section{Unit I}

Unit I includes $0-109 \mathrm{~cm}$ in GCl604, 0-14 cm in GCl605 and $0-55 \mathrm{~cm}$ in GCl606. 


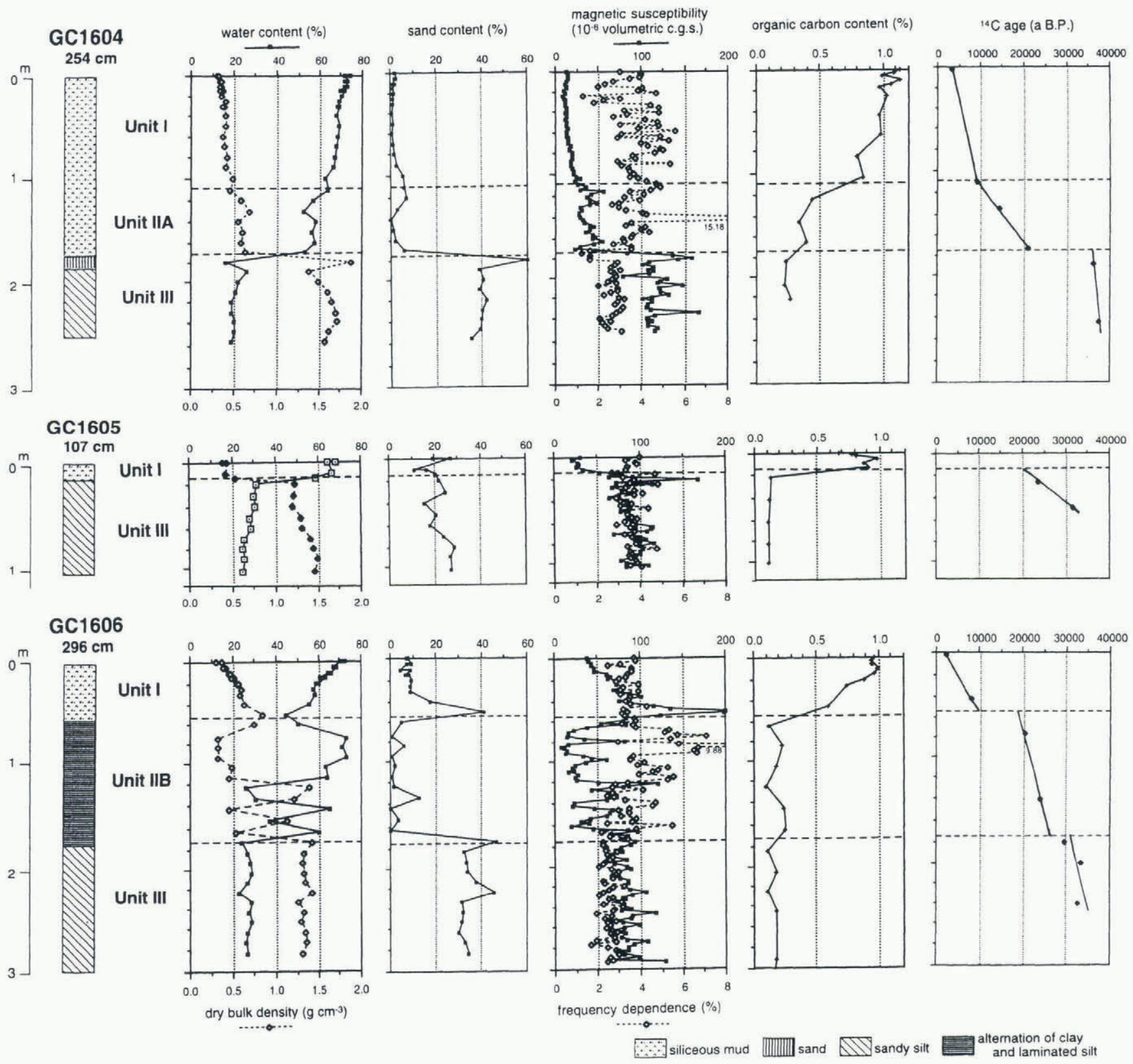

Fig. 2. Lithologies, physical properties, sand contents, carbon contents and $A M S^{14}$ Cages of the core samples from the western Ross Sea.

\section{Lithology}

Unit I is dark grayish yellow to gray olive diatomaceous mud with about $10 \%$ sand-sized grains. Water contents are generally high, averaging $60 \%$, and gradually decrease down-core. Organic carbon contents are high, exceeding $0.7 \%$.

\section{Age}

This unit is younger than $9 \mathrm{ka} \mathrm{BP}$ in two of the cores, with average sedimentation rates of $0.187 \mathrm{~mm} \mathrm{a}^{-1}$ for GCl604, and $0.060 \mathrm{~mm} \mathrm{a}^{-1}$ for GC1606. Extrapolated core-top ages for GCl604 and GC1606 are about 3 and 2 ka, respectively.

\section{Diatoms}

This unit has abundant well-preserved diatoms, with a predominance of Nitzschia curta, accompanied by Thalassiosira antarctica. These two species exceed $70 \%$ of the total in this unit.

\section{Unit IIA}

Unit IIA corresponds to $109-175 \mathrm{~cm}$ in GCl604; it is not observed in the other cores.

\section{Lithology}

Unit IIA is dark greenish gray mud, with water contents decreasing downward from $62 \%$ to $52 \%$. Organic carbon contents decrease downward from $0.8 \%$ to $0.3 \%$. Volcanic glass is abundant from 109 to $140 \mathrm{~cm}$ of this unit.

Age

The age of unit IIA is about $22-9 \mathrm{ka} \mathrm{BP}$, with a sedimentation rate of $0.056 \mathrm{~mm} \mathrm{a}^{-1}$.

\section{Diatoms}

The assemblages of unit IIA are similar to those of unit I, with the presence of Nitzschia kerguerensis and Paralia sulcata, though the diatom contents are smaller than those in unit I. Resting spores are abundant in the lower part of this unit. 

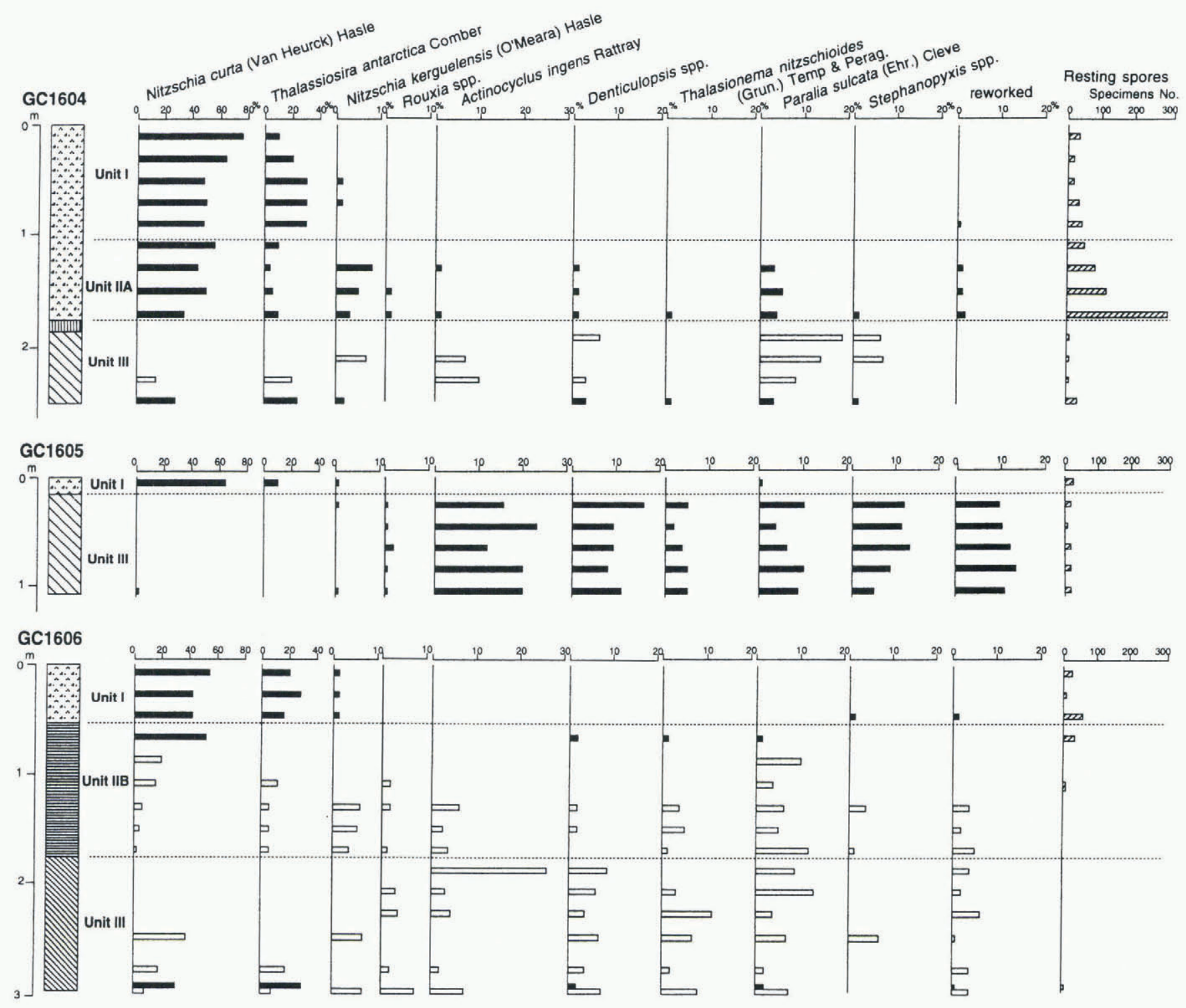

Fig. 3. Diatom distribution in cores GC1604, GC1605 and GC1606 from the western Ross Sea. Percentages of species were calculated based on identification of 100 specimens (black filled pattern) or less than 100 specimens (gray pattern). Lithologic patterns are the same as those in Figure 2.

\section{Unit IIB}

Unit IIB corresponds to $55-173 \mathrm{~cm}$ in $\mathrm{GCl} 1606$; it is not observed in the other cores.

\section{Lithology}

Unit IIB has an alternation of clay and thin ( $\mathrm{mm}$ scale) laminated silt. Water contents vary greatly between $73 \%$ and $24 \%$, and contents of sand-sized grains are low. Organic carbon contents are 3-1\%. Magnetic susceptibility is lower, and frequency dependence is greater than in the other units, which suggests that smaller magnetic grains are dominant in this unit. Several minor fault structures, apparently normal, are observed in several thin laminae of this unit.

Age

The age of unit IIB is $26-19 \mathrm{ka} \mathrm{BP}$, with a sedimentation rate of $0.20 \mathrm{~mm} \mathrm{a}^{-1}$.

\section{Diatoms}

The assemblages of unit IIB are the same as those of unit IIA, though the contents of $\mathcal{N}$. curta and T. antarctica are disdoi.org/10.3189/1998AoG27-1-275-280 Published online by Cambridge University Press
278 tinctively low. Reworked specimens are observed in this unit.

\section{Unit III}

Unit III includes $175-254 \mathrm{~cm}$ in GC1604, 14-107 cm in GCl605 and 173-296 cm in GC1606.

\section{Lithology}

Unit III is composed of consolidated dark olive gray to dark greenish gray silty sand to gravelly sandy silt, with low water contents of $18-30 \%$ and high contents of sand-sized grains exceeding $30 \%$. Organic carbon contents are $<0.2 \%$. The upper part of this unit in GC1605 is more consolidated than the lower part. Nearly all diatoms in the smear slides of this unit are fragmented.

Age

In GC1604, the two age dates in this unit are 36280 and 37460 years BP, with an apparent sedimentation of 0.483 $\mathrm{mm} \mathrm{a}^{-1}$, and the top of this unit is probably about $36 \mathrm{ka} \mathrm{BP}$ or younger. Dates of GCl605 indicate that this unit is about 20-30 ka BP, with a sedimentation rate of $0.030 \mathrm{~mm} \mathrm{a}^{-1}$. The 
ages of this unit of GCl606 are about 30-33 ka BP, and the middle and lowest age data are stratigraphically reversed.

\section{Diatoms}

This unit is composed of poorly preserved specimens of $A c$ tinocyclus ingens, $P$. sulcata, Stephanopyxis spp., and Denticulopsis $s p p$. Reworked specimens including extinct species are observed in this unit.

\section{PALEOENVIRONMENTAL RECONSTRUGTION}

The lithologic units can be used to infer the following environmental conditions for the three sites:

(1) Sediments loaded by a grounded ice sheet. Unit III has the same characteristics at all sites: high consolidation, lithologies of sandy silt with pebbly gravels, low water contents, and low organic carbon contents. This unit is correlative to diamicton, sandy basal tills widely distributed in the Ross Sea continental shelf (Anderson and others, 1991). The occurrence of diatoms and organic carbon with 23-37 ka BP AMS ages suggests that most sediments of this unit are of marine origin. The normal stratigraphic order of the AMS ages, taking error into consideration, suggests that the sediments had not been intensively deformed in this unit. Consolidation by loading probably occurred after deposition of sediments.

(2) Sediments under floating ice. Unit IIB is composed of alternating clay and laminated silt with few terrigenous coarse sand grains. The lithologies and magnetic susceptibility show an environment with little supply of terrigenous coarse materials. This unit may have been deposited under floating ice (ice shelf), preventing deposition of terrigenous coarse materials by icebergs and maintaining the supply of diatom tests and organic carbon. This environment probably persisted from at least 25 to $20 \mathrm{ka} \mathrm{BP}$ at this site. Minor normal fault structures in this lithologic unit suggest the possibility of an advance of the ice sheet or grounding icebergs between 20 and $9 \mathrm{ka} \mathrm{BP}$ at the southern site.

(3) Open marine environment with a moderate productivity influenced by shelf ice/ice sheet. Unit IIA of GCl604 is diatomaceous mud with ages between about 20 and $9 \mathrm{ka} \mathrm{BP}$ and abundant diatoms and organic carbon. Sedimentation rates are smaller than those of the upper unit of this site. The lower productivity was due to the influence of an ice shelf or an ice sheet near the site. The position of the icesheet grounding zone was probably north of this site before $20 \mathrm{ka}$ BP (Licht and others, 1996).

(4) Open marine environment with high diatom productivity. Unit I including the surface sediments of the three sites is composed of diatomaceous mud with ice-rafted sand grains, formed under similar-to-present sedimentary environments. In summer, high and variable biogenic fluxes result in high sediment accumulation in the Ross Sea (DeMaster and others, 1992). Sedimentation under modern conditions started at about $10 \mathrm{ka} \mathrm{BP}$ at sites GC1604 and GCl606.

Our age data and lithology suggest that the consolidated sandy silts of unit III were originally marine sediments. Deformation of sediments and the transportation of terrigenous debris at the base of the ice sheet are not large. The ages of organic carbon show marine deposition prior to deformation, followed by the advance of a grounded ice sheet. On this evidence, deformation corresponds to the time gap above the unit, 30-25 ka BP at the southern site and 35$21 \mathrm{ka} \mathrm{BP}$ at the northern site. The ice-sheet retreat occurred before $25 \mathrm{ka} \mathrm{BP}$, and the glacial advance event may have occurred between 20 and $9 \mathrm{ka} \mathrm{BP}$ at the southern part of the inlet including site GCl606. After about $10 \mathrm{ka}$ BP, the modern sedimentary environment was established on the Ross Sea continental shelf.

The ice sheet is thought to have covered the Ross Sea continental shelf at the Last Glacial Maximum (LGM; Anderson and others, 1991), and recent studies suggest that the ice sheet in the western Ross Sea was restricted south of $74^{\circ} \mathrm{S}$ at the LGM (Licht and others, 1996). Anderson and others (1991) classified the sediments of the Ross Sea into basal tills, transitional facies and glacial marine compound in their ice-shelf facies model and pointed out that the sharp boundaries between the basal till and the diatomaceous mud without transitional facies suggest the abrupt retreat of the ice sheet from the continental-shelf edge to the inner part of the inlet. Our data add further time constraints to the extension episode of the grounded ice sheet in the Ross Sea and provide evidence of an ice shelf north of Ross Island, following retreat of the ice shelf.

More detailed study is needed on the relations between sedimentation and drainage of glaciers in this region. It is possible that the ice sheets which influenced our three sites belonged to different drainage streams. Moreover, our ${ }^{14} \mathrm{C}$ ages are based only on correction for isotopic precipitation, but large reservoir effects are known in Antarctica (e.g. Gordon and Harkness, 1992), and ages may be altered by the addition of ${ }^{14} \mathrm{C}$-dead carbon, as indicated by reworked diatoms.

\section{CONCLUSIONS}

Sediment cores from the western margin of the Ross Sea give important indications of the sedimentary environments in the late Quaternary, as follows.

(1) Since $38 \mathrm{ka} \mathrm{BP}$ at latest, this area was a marine environment with low productivity.

(2) A grounded ice sheet advanced and loaded the sediments between about 35 and $20 \mathrm{ka} \mathrm{BP}$, forming a consolidated sandy silt unit.

(3) After $25 \mathrm{ka} \mathrm{BP}$, the southern site (about $76^{\circ} 46^{\prime} \mathrm{S}$ ) was covered by shelf ice, preventing the deposition of terrigenous coarse materials and maintaining the supply of diatom tests and organic carbon to about $20 \mathrm{ka}$ BP. The northern site (about $74^{\circ} 33^{\prime} \mathrm{S}$ ) was a marine environment with moderate productivity influenced by a proximal shelf ice/ice sheet after about $20 \mathrm{ka}$ BP.

(4) The modern marine environment began around $10 \mathrm{ka} \mathrm{BP}$.

\section{ACKNOWLEDGEMENTS}

All sediment samples and data in this study were collected during the Antarctic Geologic Survey conducted by the JNOC. We express our sincere thanks to the on-board scientists and crew members during the TH95 Cruise of R/V Hakurei-Maru. We are grateful to F. Akiba of the JAPEX 
Research Center, Japan Petroleum Exploration Co. Ltd, to T. Ishihara, S. Nakao and M. Yuasa of the Geological Survey of Japan and to E.W. Domack of Hamilton College for discussions and their kind help in the preparation of this paper. Critical reviews by W. R. Howard and P. Sedwick of the Antarctic CRC, Hobart, greatly improved the paper.

\section{REFERENGES}

Akiba, F. 1982. Late Quaternary diatom biostratigraphy of the Bellingshausen Sea, Antarctic Ocean. In . Tokyo, Japanese National Oil Corporation. Technology Research Center, 31-74. (Report 16.)

Anderson, J. B., C. F. Brake and N. C. Myers. 1984. Sedimentation on the Ross Sea continental shelf, Antarctica. Mar. Geol., 57 (1-4), 295-333.

Anderson, J. B., D. S. Kennedy, M. J. Smith and E. W. Domack. 1991. Sedimentary facies associated with Antarctica's floating ice masses. In Anderson, J. B. and G. M. Ashley, eds. Glacial marine sedimentation; paleoclimatic significance. Boulder, CO, Geological Society of America, 1-25. (GSA Special Paper 261.)

Chriss, T. and L. A. Frakes. 1972. Glacial marine sedimentation in the Ross Sea. In Adie, R. J., ed. Antarctic geology and geophysics. Oslo, Universitetsforlaget, 747-762. (International Union of Geological Sciences, Ser. B, No. 1.)

Davey, F. J. 1987. Geology and structure of the Ross Sea region. In Cooper, A. and F.J. Davey, eds. The Antarctic continental margin: geology and geophysics of the western Ross Sea. Houston, TX, Circum-Pacific Council for Energy and Mineral Resources, 1-15. (CPCEMR Earth Science Series 5B.)

DeMaster, D. J. and 7 others. 1992. Cycling and accumulation of biogenic silica and organic matter in high-latitude environments: the Ross Sea. Oceanography, 5(3), 146-153.
Denton, G. H., J. G. Bockheim, S. C. Wilson and M. Stuiver. 1989. Late Wisconsin and Early Holocene glacial history, inner Ross embayment, Antarctica. Quat. Res., 31(2), 151-182.

Edwards, B. D., H. A. Lee, E. Karl, E. Reimnitz and L. A. Timothy. 1987. Geology and physical properties of Ross Sea, Antarctica, continental shelf sediment. In Cooper, A. and F. J. Davey, eds. The Antarctic continental margin: geology and geophysics of the western Ross Sea. Houston, TX, CircumPacific Council for Energy and Mineral Resources, 191-216. (CPCEMR Earth Science Series $5 \mathrm{~B}$.

Gordon, J. E. and D. D. Harkness. 1992. Magnitude and geographic variation of the radiocarbon content in Antarctic marine life: implications for reservoir corrections in radiocarbon dating. Quat. Sci. Rev., 11 (7-8), 697-708.

Kellogg, T. B., L. E. Osterman and M. Stuiver. 1979. Late Quaternary sedimentology and benthic foraminiferal paleoecology of the Ross Sea, Antarctica. Journal of Foraminiferal Research, 9(4), 322-335.

Licht, K. J., A. E. Jennings, J.T. Andrews and K. M. Williams. 1996. Chronology of the late Wisconsin ice retreat from the western Ross Sea, Antarctica. Geology, 24(3), 223-226.

McCoy, F.W. 1991. Southern Ocean sediments: circum-Antarctic to $30^{\circ} \mathrm{S}$. In Hayes, D.E., ed. Marine geological and geophysical allas of the circum-Antarctic to $30^{\circ} \mathrm{S}$. Washington, DC, American Geophysical Union, 37-46.

Nishimura, A., M. Yuasa, T. Nakasone, M. Nakahara and N. Ioka. 1996. Sedimentological study of the sea bottom sediments of the Ross Sea continental shelf, Antarctica. Proc. NIPR Symp. Antart. Geosci. 9, 117-126.

Tokuhashi, S., C. M. Agyingi and A. Nishimura. 1996. Areal and vertical variation of heavy mineral composition of the surface sediments, Ross Sea, Antarctica. Proc. NIPR Symp. Antarct. Geosci. 9, 127-140.

Yamazaki, T. and I. Katsura. 1990. Magnetic grain size and viscous remanent magnetization of pelagic clay. F. Geophys. Res., 95(B4), 4373-4382. 